\title{
Article
}

\section{Practical precursors to reconsidering objective for physical activity in physical education}

Giblin, S., Collins, D.J., Button, C., and MacNamara, Á.

Available at https://clok.uclan.ac.uk/19074/

Giblin, S., Collins, D.J. orcid iconORCID: 0000-0002-7601-0454, Button, C., and MacNamara, Á. orcid iconORCID: 0000-0002-8110-6784 (2017) Practical precursors to reconsidering objective for physical activity in physical education. British Journal of Sports Medicine, 51 (21). pp. 1573-1574. ISSN 0306-3674

It is advisable to refer to the publisher's version if you intend to cite from the work. http://dx.doi.org/10.1136/bjsports-2017-098238

For more information about UCLan's research in this area go to http://www.uclan.ac.uk/researchgroups/ and search for <name of research Group>.

For information about Research generally at UCLan please go to http://www.uclan.ac.uk/research/

All outputs in CLoK are protected by Intellectual Property Rights law, including Copyright law. Copyright, IPR and Moral Rights for the works on this site are retained by the individual authors and/or other copyright owners. Terms and conditions for use of this material are defined in the policies page.

\section{CLoK}

Central Lancashire online Knowledge www.clok.uclan.ac.uk

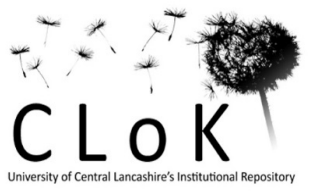




\section{Correspondence}

\section{Practical Precursors to Reconsidering Objective for Physical Activity in Physical Education}

Susan Giblin, Dave Collins, Chris Button and Áine MacNamara
Susan Giblin (corresponding author), Institute of Coaching and Performance, University of
Central Lancashire (email: SGiblin1 @ uclan.ac.uk)
Dave Collins, Institute of Coaching and Performance, University of Central Lancashire, UK /
Grey Matters Performance Ltd. (email: DJCollins@ uclan.ac.uk )
Chris Button, School of Physical Education, Sport and Exercise Sciences, University of Otago,
Dunedin. New Zealand. (email: chris.button@otago.ac.nz)
Áine MacNamara, Institute of Coaching and Performance, University of Central Lancashire
(email: AMacNamara1@uclan.ac.uk)
Word count: 399

We enjoyed and concur with the recently published editorial 'Reconsidering current objectives for physical activity within physical education' (Hobbs, Daly-Smith, McKenna et al., 2017); albeit that much of this has been said already, both by ourselves and others (Giblin, Collins, MacNamara \& Kiely, 2014; Giblin, Collins \& Button, 2014; MacNamara, Collins \& Giblin, 2015; Myer, Faigenbaum, Edwards, Clark, Best. \& Sallis, 2015). However, we do feel that the editorial missed the opportunity to consider why the balance between Physical Activity (PA) and Physical Literacy (PL) may have swung to a negative extreme. In simple terms, we suggest that this has a lot to do with the face validity and measurement of the two domains. 
Specifically, the authors highlight that governing bodies in the UK and USA currently rely upon a limited evidence base to formulate standards in physical education (PE). As highlighted by the authors, physical activity (PA) 'dose' objectives are incongruent with holistic physical literacy development paradigms (e.g. PL). The challenge, for hard-pressed primary teachers and also, perhaps, short-termist politicians, is that PA effects are easy to measure, immediate in their impact and hold 'apparently strong' face validity - lack of exercise is bad so go exercise! In contrast, PL initiatives are hard to measure so an empirical evidence base is lacking, despite a growing body of support for PL being the best solution for promoting lifelong PA.

Unfortunately, there is currently no robust empirical tool for evidencing skill learning in the physical movement component of PL. This presents a serious limitation to the design of, and claims that can be made for, such interventions. Accordingly, we are undertaking development and validation of an active gaming-based test of movement competence in children. From a practical perspective, data from the active gaming assessment is objectively and efficiently ( $~ 8$ mins per test) recorded on a per child basis. Time and resources required to deploy the tests are small compared to the cumbersome set-up and preparative requirements of other tests. Additionally, in context of the practical example described in the editorial, assessment can focus on self-regulated execution of skills in a range of tasks to measure individuals' learning and skill progression over time. This offers a more individualised and less rigid form of assessment that is reflective of contemporary dynamical theories of motor performance (Chow, 2013). We suggest that the evaluation and, hopefully, substantiation of claims made for PL is the essential next step for driving towards a more balanced and effective curriculum. 


\section{References}

Chow, J. Y. (2013). Nonlinear learning underpinning pedagogy: Evidence, challenges, and implications. Quest, 65(4), 469-484.

Giblin, S., Collins, D., \& Button, C. (2014). Physical literacy: Importance, assessment and future directions. Sports Medicine, 44(9), 1177-1184. doi:10.1007/s40279-014-0205-7

Giblin, S., Collins, D., MacNamara, A., \& Kiely, J. (2014). 'Deliberate Preparation' as an evidence-based focus for primary physical education. Quest, 66(4), 385-395.

doi:10.1080/00336297.2014.944716

Hobbs, M., Daly-Smith, A., McKenna, J., Quarmby, T., \& Morley, D. (2017). Reconsidering current objectives for physical activity within physical education.

MacNamara, Á., Collins, D., \& Giblin, S. (2015). Just let them play? Deliberate preparation as the most appropriate foundation for lifelong physical activity. Frontiers in Psychology, 6, . doi:10.3389/fpsyg.2015.01548

Myer, G.D., Faigenbaum, A.D., Edwards, N.M, Clark, J.F., Best, T.M. \& Sallis, R.E. (2015) Sixty minutes of what? A developing brain perspective for activating children with an integrative exercise approach. British Journal of Sports Medicine, 49, 23 http://dx.doi.org/10.1136/bjsports2014-093661 